\title{
Fenomena Pernikahan Dini Membuat Orang Tua dan Remaja Tidak Takut Mengalami Kehamilan Tidak Diinginkan
}

\author{
Aprianti $^{*}$, Zahroh Shaluhiyah ${ }^{* *}$, Antono Suryoputro ${ }^{* *}$ Ratih Indraswari** \\ *) Fakultas Kesehatan Masyarakat, Universitas Andalas \\ Korespondensi: aprianty17@gmail.com \\ **) Fakultas Kesehatan Masyarakat, Universitas Diponegoro
}

\begin{abstract}
Abstrak
Kasus KTD pada remaja Kabupaten Pati yang berusia $<17$ tahun sebanyak 43,8\%, yang berdampak pada pernikahan di usia dini semakin meningkat. Penelitian ini bertujuan untuk mendeskripsikan respon orang tua dan remaja SMP yang mengalami KTD, serta dampak pernikahan di usia dini. Metode penelitian ini adalah kualitatif dengan desain studi kasus. Pengambilan sampel dengan cara purposive dan pengumpulan data menggunakan indepth interview. Informan utama adalah remaja yang mengalami KTD 5 orang. Informan triangulasi orang tua informan 5 orang. Hasil penelitian menunjukan fenomena pernikahan dini membuat orang tua dan remaja tidak takut mengalami kehamilan tidak diinginkan, akibatnya masyarakat yang dahulu menganggap hubungan seks pranikah perilaku yang melanggar norma, sekarang cenderung lebih bisa diterima oleh masyarakat. Orang tua dan remaja yang tinggal didaerah rural memberikan respon untuk menyelesaikan permasalah KTD dengan menikahkan informan. Sedangkan yang tinggal didaerah urban, meminta informan untuk melakukan aborsi, tetapi setelah gagal akhirnya informan dinikahkan. Pernikahan menjadi solusi KTD yang dialami remaja karena masyarakat permisif terhadap pernikahan diusia dini dan budaya dimasyarakat yang menganggap jika kewajiban perempuan hanya disektor domestik, sehingga kodrat perempuan adalah menjadi ibu urmah tangga. Disarankan memberikan informasi kepada remaja dan orang tua tentang dampak pernikahan dini. Pemerintah khususnya DKK Pati bisa lebih memberikan pelayanan kesehatan yang ramah remaja sejak tingkat SMP.

Kata kunci : KTD, pernikahan dini, remaja SMP
\end{abstract}

\section{Abstract}

In Pati District KTD cases in adolescents aged $<17$ years as much as $43.8 \%$, which affects the marriage at an early age is increasing. This research aims to describe the response of parents and teens junior who experience unwanted pregnancy, and the effects of marriage at an early age. This research method was qualitative case study design. With a purposive sampling and data collection using in-depth interviews. The main informants were adolescent who experienced unwanted pregnancy 5 people. Informants triangulation parents 5 people. The results showed the phenomenon of early marriage makes parents and teens are not afraid of an unwanted pregnancy, as a result people who previously regarded premarital sex behavior that violates norms, are now more likely to be accepted by society. Parents and teenagers who live rural areas provide a response to resolve the problem by marrying unwanted pregnancy informant. While living urban areas, asking informants to have an abortion, but after failing informant eventually wed. Marriage was a solution unwanted pregnancy experienced by adolescents because of the permissive society towards marriage early age and culture in the community who think if the domestic sector only female duties, so that the nature of women is to be a housewife. Suggested provide information to adolescents and parents about the effects of early marriage. The government particularly Health Provider can further provide youthfriendly health services since the junior level.

Keywords: unwanted pregnancy, early marriage, adolescents of junior high school 


\section{PENDAHULUAN}

Jumlah penduduk Indonesia tahun 2010 sebanyak 237,6 juta jiwa, 26,67\% diantaranya adalah remaja.(BPS, 2010) Banyak remaja mengalami maturity-gap yaitu perbedaan kematangan secara fisik dan mental. Perbedaan kematangan ini dapat mendorong remaja untuk melakukan hal-hal yang beresiko.(Jackson and Goossens, 2006) Kematangan seks yang lebih cepat dengan dibarengi makin lamanya usia untuk menikah menjadi salah satu penyebab meningkatnya jumlah remaja yang melakukan hubungan seks pranikah.(Musthofa and Winarti, 2010)

Salah satu akibat dari perilaku seks pranikah remaja adalah kehamilan tidak diinginkan (KTD). KTD adalah kehamilan yang dialami oleh seorang perempuan yang sebenarnya belum atau sudah tidak menginginkan hamil.(Azinar, 2013) Menurut Sadik setiap tahunnya, dari 175 juta kehamilan yang terjadi di dunia terdapat sekitar 75 juta perempuan yang mengalami KTD. Sementara menurut Henshaw 80\% kehamilan remaja di Amerika adalah tidak diinginkan.(Neamsakul, 2008) Jumlah KTD di Indonesia belum dapat ditentukan secara pasti. Jika ada, maka sifatnya hanya data regional di suatu daerah, biasanya data tersebut diperoleh dari pelaksanaan program kesehatan reproduksi maupun data dari PKBI.
Pengambil keputusan saat remaja menghadapi KTD lebih banyak dilakukan keluarga. Hasil penelitian oleh Khisbiyah, menyebutkan bahwa pada proses pengambilan keputusan untuk melanjutkan kehamilan, dari 26 informan. Inisiator paling besar adalah orang tua $50 \%$, informan dan pasangan $30,8 \%$, informan saja $11,5 \%$ dan pasangan saja 7,7\%.(khisbiyah yayah, 1994) Hal ini juga didukng oleh PKBI yang menyebutkan bahwa pilihan-pilhan yang dibuat oleh remaja perempuan dalam menghadapi KTD adalah pilihan yang “dibuatkan" oleh kekuasaan keluarga dan atau pasangannya. Pilihan -pilhan tersebut meliputi melanjutkan kehamilan dengan menikah atau tidak menikah, melanjutkan kehamilan dengan merawat sendiri anak yang dilahirkan atau menjadikan anak tersebut sebagai anak adopsi, atau aborsi.(PKBI, 2011)

Pilihan yang diambiil orang tua dalam menghadapi KTD paling banyak adalah menikahkan remaja, karena dengan menikahkan remaja yang KTD dapat menutupi rasa malu keluarga dan dianggap cara yang paling efektif menyelesaikaikan permasalahan KTD. Meskipun usia remaja yang masih dini untuk menikah tidak menjadi permasalahan bagi keluarga, karena budaya masyarakat Indonesia yang menerima pernikahan diusia dini. Hal tersebut didukung dengan data Riset Kesehatan Dasar (Riskesdas) 2013 yang 
dilakukan Kementerian Kesehatan RI mengungkapkan bahwa di antara perempuan 10-54 tahun, 2,6\% menikah pertama kali pada umur kurang dari 15 tahun, dan 23,9\% menikah pada umur 15-19 tahun. Ini berarti sekitar $26 \%$ perempuan di bawah umur telah menikah. Dalam konteks regional ASEAN angka perkawinan anak di Indonesia adalah tertinggi kedua setelah Kamboja. (Kartikawati, 2014)

Selanjutnya, berdasarkan penelitian dari Ilika dan Anthony respon remaja yang mengalami KTD merasa khawatir tingkat tinggi, mendapatkan stressor dari perasaan stigma 98,6\%, kekecewaan dari orang tua 95,6\%, dikeluarkan dari sekolah 41,2\%, sanksi agama 52,9\%, reaksi negatif dari pasangan $94 \%$, dan merasa takut terkena IMS/HIV hanya $8,8 \%$. Dari hal tersebut terlihat bahwa stressor yang paling dirasakan berat dari remaja adalah stressor dari lingkungannya.(Ilika and Igwegbe, 2004)

Angka Kematian Ibu (AKI) di Indonesia pada tahun 2012 masih tinggi yaitu 359 per 100.000 kelahiran hidup. Berdasarkan SDKI tahun 2012 angka kematian neonatal paling banyak terjadi pada ibu hamil yang berusia kurang dari 20 tahun sebesar 33\%. Provinsi dan kabupaten dengan jumlah kematian ibu dan neonatal yang besar, diantaranya adalah Jawa Tengah.(BKKBN, 2013) Selanjutnya, Kabupaten Pati merupakan salah satu kabupaten di Jawa Tengah. Berdasarkan data di Kabupaten Pati terdapat remaja yang mengalami KTD sebesar 84 kasus dan yang berusia dibawah 17 tahun sebanyak 19 kasus dengan usia paling muda saat hamil adalah 13 tahun.(Dinas Kesehatan Kabupaten Pati, 2016)

Banyak penelitian yang telah membahas terkait perilaku seks pranikah serta faktor - faktor yang mempengaruhinya. Namun penelitian mengenai respon orang tua dan remaja SMP yang mengalami KTD masih jarang dilakukan. Semakin rendah usia seseorang wanita menjadi hamil, semakin besar risiko kesehatannya. Semakin awal remaja melakukan aktivitas seksualnya semakin berisiko untuk terjadinya penularan infeksi menular seksual, temasuk HIV/AIDS. Serta semakin berat beban psikologis yang dialami remaja saat sedang hamil akan meningkatkan risiko terjadinya kematian ibu.

\section{METODA}

Penelitian ini menggunakan metode qualitative dengan desain studi kasus yang bertujuan untuk mendeskripsikan respon orang tua dan remaja SMP yang mengalami kejadian KTD di Kabupaten Pati. Pemilihan informan dilakukan secara purposive sampling dengan kriteria: Remaja yang berusia dibawah 17 tahun, mengalami KTD pada tahun 2015, memiliki orang tua dan bersedia menjadi informan penelitian. 
Pengumpulan data dilakukan dengan cara wawancara mendalam, dengan alat bantu berupa panduan wawancara dan perekam suara. Dalam menjangkau informan peneliti dibantu oleh bidan desa dan perangkat desa. Langkah awal penelitian dimulai dari peneliti melakukan pendekatan dengan bidan desa untuk mendapatkan data remaja yang mengalami KTD serta mendapatkan gambaran umum dari remaja tersebut. Terdapat delapan informan, namun dua informan tidak dapat ditemui karena mengalami depresi berat, dan satu informa menolak untuk diwawancarai. Sampai akhir penelitian terdapat lima informan yang berhasil dilakukan pengumpulan data. Informan triangulasi 5 orang yaitu orang tua informan. Pemilihan informan dibedakan menjadi dua kategori yaitu, informan yang berasal dari daerah rural dan urban. Adapun analisis data dilakukan secara thematic content analysis. (Ghony, 1997)

\section{HASIL DAN PEMBAHASAN}

Tabel 1 Menunjukan Informan utama termasuk dalam kategori usia remaja awal dan tengah. Remaja awal dan menengah mempunyai ciri - ciri yaitu, tampak dan memang merasa lebih dekat dengan teman sebaya, tampak dan merasa ingin bebas, tampak dan ingin mencari identitas diri, ada keinginan untuk berkencan atau ketertarikan pada lawan jenis, timbul perasaan cinta yang mendalam, kemampuan berfikir abstrak (berkhayal) makin berkembang.

$$
\text { Rata - rata pendidikan informan }
$$

tamat SMP. Jenis tempat tinggal bersama dengan orang tua. Menurut Hurlock bentuk keluarga mempengaruhi pembentukan kepribadian dan tingkah laku seorang anak. Menurut Ali dan Asrori tidak hanya tipe keluarga yang berpengaruh namun juga dapat dibebakan oleh salah satu ciri khas remaja selalu bersikap menentang. Ciri khas ini bila tidak diimbangi dengan bekal pengetahuan yang matang maka remaja akan dengan mudah terjerumus ke perilaku menyimpang, salah satunya adalah perilaku seksual pranikah yang berisiko tinggi.(Ali and Asrori, 2010) Hanya satu informan yang belum menikah karena pasangannya kabur tidak mau bertanggung jawab. Orang tua informan yang diwawancarai dalam penelitian ini adalah ibu informan karena berdasarkan keterangan informan utama mereka lebih dekat dengan ibu, hanya satu informan yang diwawancarai adalah bapak karena ibunya telah meninggal. 
Tabel 1. Karakteristik Informan

\begin{tabular}{|c|c|c|c|c|c|c|c|}
\hline No & $\begin{array}{l}\text { Inisial } \\
\text { Informan }\end{array}$ & $\begin{array}{l}\text { Umur } \\
\text { (tahun) }\end{array}$ & $\begin{array}{l}\text { Status } \\
\text { pernikahan }\end{array}$ & $\begin{array}{l}\text { Pendidikan } \\
\text { terakhir }\end{array}$ & Agama & $\begin{array}{l}\text { Jenis tempat } \\
\text { tinggal }\end{array}$ & $\begin{array}{l}\text { Tempat } \\
\text { tinggal }\end{array}$ \\
\hline 1 & R1 & 15 & Menikah & SMP & Islam & $\begin{array}{l}\text { Rumah } \\
\text { orang tua }\end{array}$ & rural \\
\hline 2 & $\mathrm{R} 2$ & 16 & Menikah & SMP & Islam & $\begin{array}{l}\text { Rumah } \\
\text { orang tua }\end{array}$ & urban \\
\hline 3 & R3 & 13 & Menikah & SD & Islam & $\begin{array}{l}\text { Rumah } \\
\text { orang tua }\end{array}$ & Rural \\
\hline 4 & $\mathrm{R} 4$ & 14 & Menikah & $\begin{array}{l}\text { Tidak tamat } \\
\text { SD }\end{array}$ & Islam & $\begin{array}{l}\text { Rumah } \\
\text { mertua }\end{array}$ & urban \\
\hline 5 & R5 & 16 & $\begin{array}{l}\text { Belum } \\
\text { menikah }\end{array}$ & SMP & Islam & $\begin{array}{l}\text { Rumah } \\
\text { majikan }\end{array}$ & Rural \\
\hline
\end{tabular}

Tabel 2. Karakteristik Orang Tua Informan

\begin{tabular}{llllll}
\hline Variabel & \multicolumn{5}{c}{ Informan } \\
\cline { 2 - 6 } & R1 & R2 & R3 & R4 & R5 \\
\hline Inisial orang tua & Dn & Ls & Nf & Sf & An \\
\hline $\begin{array}{l}\text { Status } \\
\text { pernikahan }\end{array}$ & Menikah & Menikah & Menikah & Menikah & Cerai Mati \\
\hline $\begin{array}{l}\text { Tingkat } \\
\text { Pendidikan }\end{array}$ & SD & SMP & SMP & SMP & SD \\
\hline Agama & Islam & Islam & Islam & Islam & Islam \\
\hline Jenis Pekerjaan & Pedagang & $\begin{array}{l}\text { Pembantu } \\
\text { rumah tangga }\end{array}$ & Pedagang & Pedagang & Petani \\
\hline
\end{tabular}

Tingkat pendidikan biasanya Tipe keluarga informan mayoritas berkolerasi dengan tingkat pengetahuan. merupakan keluarga inti, yaitu keluarga Pengetahuan orang tua terkait masalah yang terdiri dari bapak ibu dan anak. seksual dan reproduksi remaja juga memiliki Selanjutnya pekerjaan orang tua informan pengaruh terhadap pemberian pendidikan seksual oleh orang tua kepada remajanya. Orang tua sering memberikan pengetahuan yang tidak akurat tentang kesehatan reproduksi dan pengendalian kelahiran. (Ayalew, Mengistie and Semahegn, 2014) Orang tua sering memberikan pengetahuan yang tidak akurat tentang kesehatan reproduksi dan pengendalian kelahiran. mayoritas bekerja sebagai pedagang.

Respon yang seseorang berikan berhubungan erat dengan faktor kepribadian dari dalam dirinya serta dari faktor luar dirinya yaitu masyarakat sekitar.(Petronio, 2002) Dalam penelitian ini respon orang tua yang tinggal didaerah rural marah, kaget, malu dengan masyarakat sekitar dan kecewa dengan informan.

(Ayalew, Mengistie and Semahegn, 2014). 
"Perasaaan saya hancur, dia tak marahi, kecewa pasti mbak, malu sama tetangga kan nama ne wajah ya mbak mau gimana giman gak bisa ditutupi"'(DN orang tua Rl, 15 tahun)

Orang tua informan yang tinggal didaerah urban memberikan respon dengan melakukan kekerasan fisik dan psikis pada informan. Kekerasan fisik diterima juga dari kakak kandungnya, seperti yang dialami oleh informan R2.

"Ibu ya marah - marah mbak bilang nek kecewa orang udah dibiayi sekolah mahal mahal tapi kok malah gini....kakak terus mukuli aku"'(R2, 16 tahun)

Berdasarkan data tersebut terlihat perbedaan stressor orang tua yang tinggal didaerah rural stressornya adalah rasa malu dengan masyaraat sekitar, sedangkan pada masyarakat urban stressornya karena memikirkan masa depan informan yang tidak dapat bersekolah lagi.

Orang tua informan yang tinggal di daerah rural memikirkan untuk menikahkan putrinya karena jika harus melakukan aborsi takut akan menambah dosa. Orang tua informan R3 merasa lebih tenang anaknya menikah karena usia pasangan yang sudah dewasa dan bekerja sehingga dapat menjadi kepala keluarga yang baik, meskipun usia informan masih sangat muda yaitu 13 tahun.
Hasil penelitian ini sesuai dengan penelitian yang dilakukan oleh Khisbiyah, yaitu bahwa banyak orang tua yang kecewa dan marah besar begitu mendengar kehamilan anak remajanya. Namun, pada akhirnya mereka dapat menerima kehamilan tersebut dan tidak mendukung aborsi karena takut dosa dua kali lipat. Keputusan selanjutnya adalah orang tua remaja perempuan biasanya memusyawarahkan masalah ini dengan pacar anak remajanya dan orang tua sang pacar. Akhirnya kedua anak remaja tersebut dinikahkan.(khisbiyah yayah, 1994)

"Ya saya kepikiran untuk menikahkan karena buat orang islam kan gak boleh digugurin, soalnya kan kalau dihilangin ya tambah dosa...pas cucu udah lahir ya senang sudah anggap itu rezeki dari Allah"(DN orang tua R1 15 tahun)

“Wes pokok e ono sing tanggung jawab aku wes ayem, Sing lanang e tak kon moro tanggung jawab, terus yo langsung dinikahkan, wedi ku nek malah karo koncone sekolah" (NF orang tua R3 13 tahun)

Orang tua informan R5 sebenarnya ingin menikahkan putrinya namun lelaki yang menghamilinya kabur. Untuk menemukan lelaki tersebut membutuhkan banyak dana, padahal keluarga mereka termasuk keluarga ekonomi menengah kebawah, akhirnya orang tua informan R5 
memutuskan untuk sabar dan ikhlas dalam menerima semua kejadian tersebut. Terlebih orang tua merupakan tokoh agama di daerah tersebut dan sangat taat kepada agama sehingga untuk melakukan aborsi sangat tidak dimungkinkan.

"Nek coro usaha koyok opo bahan e (uang) gak ono wae tetap gak iso misal e diongkosi yo kudu butuh ongkose yo akeh, nek didelok soko kebatinan iku anci wes dadi nasib e dia, dadi yo pasrah ditompo opo anane wae. Wes ditakdir ke ngene")(AN orang tua R5 16 tahun)

Namun menurut pengakuan informan R5 sebelum dia melakukan private disclosure kepada orang tua, dia telah mencoba melakukan aborsi sesuai saran yang diberikan pasangannya. Informasi mengenai cara aborsi yang dilakukan didapat dari pasangannya. Cara cara yang ditempuh informan untuk melakukan aborsi dengan cara aborsi sendiri yaitu dengan minum obat pelancar haid, minum jamu - jamu serta tindakan lain seperti loncat - loncat memukuli perut dan memakai pakaian yang ketat. Aborsi yang dilakukan oleh informan termasuk dalam Aborsi provocatus criminalis, yaitu pengguguran yang dilakukan tanpa dasar indikasi medis, dan hal tersebut masih merupakan hal ilegal di Indonesia.
"Dia terus ngakon aku ngilangke, ditukokne jamu, obat, nganti digowo nek dukun bayi kon ngurut... ning gak iso ilang - ilang..." (R5, 16 tahun)"

Sementara orang tua informan R4 meminta informan untuk melakukan aborsi karena tidak suka dengan lelaki yang menghamili, karena terlalu tua dan dianggap tidak mampu memenuhi kebubutuhan informan.

“arep tak ilangno (aborsi) la piye e mbak anak ku iseh cilik e ngno kawin tek entok wong tua, lah nek wong tuo ne sugeh, bener iso noto anak ku sing dadi apik yo ora opoopo, la iki wes gak sugeh, gak mudengan, pikiran e yo aneh"(SF orang tua R4 14 tahun)

Orang tua informan didaerah urban, memutuskan mencoba melakukan aborsi kepada putrinya, mengingat usia putrinya yang masih muda dan ingin putrinya kembali sekolah, Usaha - usaha yang dilakukan untuk aborsi sama dengan yang dilakukan oleh informan R5. Setelah mencoba melakukan aborsi urang lebih satu bulan dan gagal melakukan aborsi maka tahap terakhir adalah unvoidable accetancel penerimaan yang tidak bisa dihindari orang tua bisa menerima kehamilan informan karena orang tua merasa kejadian tersebut sudah terlanjur terjadi, hingga mau tidak 
mau mereka harus menerimanya. (Neamsakul, 2008) Pada umumnya informan mengaku jika sudah hamil diusia kehamilan yang masuk empat bulan sehingga sulit untuk diaborsi dengan cara tradisional.

"mau tak hilangi (aborsi) biar sekolah lagi orang masih muda” (Ls, orang tua R2)

Berdasarkan respon orang tua tersebut dapat ditangkap suatu fenomena Jika pada informan yang tinggal di daerah rural cenderung memberikan respon menikahkan remaja yang mengalami KTD dengan tujuan menyelesaikan masalah, dimana pada masyarakat rural cenderung lebih menerima pernikahan muda sebagai dampak dari kehamilan tidak diinginkan. Berbeda halnya dengan informan yang tinggal didaerah urban, dimana respon orang tua adalah dengan ingin melakukan aborsi kepada informan karena orang tua informan menganggap jika informan terlalu muda untuk menikah dan dengan menikah akan menghilangkan kesempatan informan untuk menempuh pendidikan yang tinggi dan meraih kesempatan bekerja yang baik, meskipun setelah usaha aborsi yang dilakukan gagal orang tua akhirnya menikahkan informan. Hasil penelitian sesuai dengan data Analisis survei penduduk antar sensus (SUPAS) 2005 dari Badan Koordinasi Keluarga Berencana Nasional
(BKKBN) didapatkan angka pernikahan di perkotaan lebih rendah dibanding di pedesaan, untuk kelompok umur 15-19 tahun perbedaannya cukup tinggi yaitu $5,28 \%$ di perkotaan dan $11,88 \%$ di pedesaan.(Palu, 2008) Hal ini menunjukkan bahwa pernikahan pada usia muda lebih bisa diterima oleh masyarakat rural.

Peneriman masyarakat rural terhadap pernikahan dini pada perempuan tidak terlepas dari pandangan subordinasi pada perempuan, yaitu perempuan hanya bekerja pada sektor domestik yang memiliki tanggung jawab untuk mengurusi rumah dan anak. Sehingga tidak ada tuntutan untuk perempuan memiliki pendidikan yang tinggi. Akibatnya jika terdapat perempuan yang mengalami KTD maka akan dinikahkan karena menganggap pendidikan tidak penting bagi perempuan. Bias gender tersebut dapat terjadi karena dominasi budaya patriarki yang dianut oleh masyarakat Indonesia pada umumnya. Selain itu dapat disebabkan agama informan keselurah adalah beragama islam bias gender dapat muncul akibat salah dalam pemahaman agama. Kesalahan pemahaman agama tersebut, yaitu pertama pada umumnya umat islam lebih banyak memahami agama secara dogmatis, bukan berdasarkan penalaran yang kritis khususnya pengetahuan agama yang menjelaskan peranan dan kedudukan perempuan,kedua pada umumnya masyarakat memperoleh 
pengetahuan keagamaan melalui ceramah dari para ulama yang umumnya sangat bias gender, bukan berdasarkan kajian kritis yang mendalam terhadap sumber - sumber aslinya (Al - Qur'an dan Sunnah). Ketiga pemahaman tentang relasi laki - laki dan perempuan dimasyarakat lebih banyak mengacu kepada pemahaman tekstual terhapa teks - teks suci sehingga mengabaikan kontekstualnya yang lebih egalitir dan akomodatif terhadap nilai - nilai kemanusiaan.(Mulia, 2007)

Selanjutnya lingkungan masyarakat urban cenderung individualistis dan realistik, sehingga orang tua informan tidak terlalu memikirkan penilaian masyarakat sekitar karena pada umumnya masyarakat sekitar juga tidak terlalu mempedulikan tentang kehidupan keluarga lain. Masyarakat cenderung berpikir realistik jika dengan menikah muda akan menutup kesempatan remaja untuk mendapatkan pendidikan yang tinggi agar dapat mendapatkan pekerjaan yang layak. Fenomena seperti itulah yang membuat orang tua informan memilih untuk melakukan aborsi kepada informan. Hasil penelitian ini sejalan dengan penelitian yang dlakukan oleh Hertanti, dimana hasil peneltiannya menunjukan jika resiko sosial yang didapat setelah melakukan aborsi ternyata jauh dari anggapan masyarakat selama ini.. Para subyek justru mendapat perhatian yang positif dari teman - temannya dan tidak dijauhi oleh teman-temannya. Masyarakat urban lebih mudah menerima adanya perubahan sosial, lebih individualistik, dan tidak mau ikut campur dalam urusan orang lain, sehingga mereka tidak akan langsung memberikan stigma negatif pada remaja yang telah melakukan aborsi karena telah melakukan dosa yang besar.(Andire, 2012) Selain itu didukung juga oleh data yang dari penelitian Djamilah, yaitu sebagai ibukota negara Republik Indonesia, DKI Jakarta merupakan titik pertemuan nasional dari berbagai aspek kehidupan.Kehamilan tidak terencana terjadi pada usia perkawinan dengan usia muda 16 - 20 tahun (51,7\%), sekitar 6,71\% di antaranya sengaja digugurkan. Provinsi di mana ibu banyak melakukan aborsi, berturut-turut adalah Jawa Barat, DKI Jakarta, Jawa Timur dan Jawa Tengah. (Kartikawati, 2014)

Status pernikahan pada remaja yang mengalami KTD berdampak pada praktik informan menjaga kesehatan dirinya dan kehamilannya. informan yang telah menikah, dengan dukungan dari orang tua serta pasangan telah melakukan antenatal care (ANC) secara rutin dibandingkan remaja yang belum menikah.

"Iya priksa setiap satu bulan sekali biasanya ditemani ibu kadang juga pernah sama suami" (R2, 16 tahun) 
"kadang priksa mbak nek pas ono sing tak rasakne gak penak wae" (R5, 16 tahun)

Hal ini sesuai dengan penelitian yang dilakukan oleh Dini, ibu yang mengalami kehamilan tidak diinginkan mempunyai peluang untuk tidak melakukan perawatan kehamilan, yaitu ANC 1,79 kali dibandingkan ibu yang kehamilannya diinginkan.(Dini, Riono and Sulistiyowati, 2016)

Selain itu, Informan yang sudah menikah telah mencoba menerapkan pola hidup sehat yaitu dengan berolahraga secara teratur setiap pagi, istirahat yang cukup dan makan yang teratur. Sedangkan informan yang belum menikah tidak pernah mencoba menerapkan pola hidup sehat karena tidak memiliki niat untuk mempertahankan kehamilannya.

"Kalau makan gak sama kayak biasa, Cuma kalau kata - kata orang gak boleh makan udang sama terong ya ngikut aja...kalau pagi disuruh jalan - jalan sama ibu sama suami.. . ya tidur mbak tapi gak bisa tenang gitu tidurnya” (R1, 15 tahun)

“Gak pernah nglakoni hidup sehat biasa wae seperti biasane soal e... awal e pngen dihilangke wae" (R5, 16 tahun)

Dalam menghadapi permasalahan terkait KTD nya orang yang paling berperan bagi informan ada;ah orang tua informan, terutama ibu informan.

"Ibu selalu ngingetin buat makan sama olahraga mbak, kadang juga nemenin priksa” (R1, 15 tahun)

"Gak ada sih mbak kalau pas hamil, soalnya gak pernah priksa sih mbak sama bidan desa" (R1, 15 tahun)

Hasil penelitian ini dengan penelitian yang telah dilakukan oleh Sriyasak yaitu dukungan sosal dari keluarga bepengaruh terhadap minat remaja yang menjadi ibu pada anak pertama untuk melakukan akses ke pelayanan kesehatan.(Sriyasak, Akerlind and Akhavan, 2013) Sedangkan peran bidan desa dalam membantu informan menjaga kehamilannya dirasa tidak terlalu penting bagi semua informan. Hal tersebut disebabkan informan belum begitu memahami peran yang harus dilakukan bidan desa. Sepengetahuan informan bidan desa hanya sebagai penyedia pelayanan kesehatan yang berarti informan berhak mendapatkan pelayanan kesehatan apabila datang ke tempat praktik bidan desa tersebut.

Berdasarkan hasil penelitian ini dapat disimpulkan jika menikah merupakan solusi atau pilihan yang diambil oleh orang tua untuk menyelesaikan masalah KTD yang dialami informan, tanpa orang tua memikirkan dampak yang akan dialami 
remaja yang menikah di usia dini. Pernikahan dini pada remaja memberikan konsekuensi yang panjang bagi remaja. dampak yang dialami remaja perempuan tidak hanya, masalah kesehatan reproduksi dimana anak perempuan berusia 10-14 tahun memiliki kemungkinan meninggal lima kali lebih besar, di masa kehamilan atau melahirkan, dibandingkan dengan perempuan berusia 20-25 tahun. (Fadlyana, E., Larasaty, 2009)

Persoalan tingginya Angka Kematian Ibu (AKI) melahirkan tersebut semakin diperparah oleh kuatnya pengaruh budaya patriarkhi yang melingkupi kehidupan masyarakat. Masyarakat masih menganut bahwa perempuan itu lemah sehingga jika mereka mengalami kesulitan, penderitaan atau bahkan kematian akibat melahirkan dianggap sebagai hal yang lumrah atau wajar. Masyarakat masih menganut pandangan bahwa hamil dan melahirkan merupakan kodrat perempuan. Karena itu, penderitaan dan kesakitan, bahkan kematian yang dialami perempuan sebagai akibat dari fungsi - fungsi reproduksinya itu juga merupakan "kodrat" yang seharusnya ditanggung oleh perempuan. Akibatnya, penanganan kesakitan dan penderitaan selama hamil dan penurunan angka kematian ibu bersalin sangat lambat dan kurang mendapat perhatian serius dari masyarakat, termasuk dari kaum perempuan itu sendiri. Pada umumnya masyarakat memahami bahwa ibu yang meninggal ketika melahirkan adalah mati syahid dan dijamin masuk surga. Implikasinya, kematian ibu tidak dijamin masuk surga juga. Kalaupun pemahaman tersebut diyakini kebenarannya, namun setiap ibu pun punya hak untuk menikmati hidup atau tidak masuk surga secepatnya. (Mulia, 2007)

\section{SIMPULAN}

Respon orang tua yang tinggal didaerah rural ingin menikahkan informan, sedangkan respon orang tua yang tinggal didaerah urban ingin melakukan aborsi akan tetapi setelah gagal kemudian menikahkan informan sebagai solusi atas kejadian KTD. Pernikahan menjadi solusi atas kejadian KTD karena masyarakat cenderung permisif terhadap pernikahan diusia muda dan adanya bias gender jika perempuan hanya memiliki tanggung jawab disektor domestik. Akibatnya orang tua dan remaja tidak takut mengalami KTD. Orang tua kurang memahami mengenai dampak yang akan timbul dari pernikahan di usia dini. Selain beresiko terhadap kesehatan remaja selama hamil dan melahirkan, pernikahan diusia muda juga membawa banyak konsekuensi terkait aspek psikologis, sosial, dan ekonomi remaja.

Perlunya memberikan informasi kepada remaja dan orangtua tentang dampak pernikahan pada usia dini terkait asepk 
kesehatan, psikologis maupun fisiologis.

Dinas kesehatan perlu meningkatkan kinerja bidan desa dalam mendampingi remaja yang mengalami KTD dan memberikan pelayanan ramah remaja sejak tingkat SMP untuk mencegah kejadian KTD pada remaja yang lain.

\section{KEPUSTAKAAN}

Ali, M. and Asrori, M. (2010) Psikologi Remaja: Perkembangan Peserta Didik. Bandung: Bumi Aksara.

Andire, H. (2012) 'Aborsi (Studi Deskriptif Tentang Proses Pengambilan Keputusan Aborsi Ilegal yang Dilakukan oleh Remaja Putri diKota Surabaya)', Jurnal Sosial dan Politik UNAIR. Available at: journal.unair.ac.id/downloadfullpapers-JURNAL ANDRIE 070914051.pdf.

Ayalew, M., Mengistie, B. and Semahegn,

A (2014) 'Adolescent-parent communication on sexual and reproductive health issues among high school students in Dire Dawa, Eastern Ethiopia: a cross sectional study.', Reproductive health, 11(1), p. 77. doi: 10.1186/1742-4755-1177.

Azinar, M. (2013) 'Perilaku Seksual Pranikah Berisiko Terhadap Kehamilan Tidak Dinginkan', Jurnal Kesehatan Masyarakat, 8(2), pp.
153-160.

doi:

10.15294/kemas.v8i2.2639.

BKKBN (2013) Survei Demografi dan Kesehatan Indonesia 2012. Jakarta:

Badan Pusat Statistik.

BPS (2010) Hasil Sensus Penduduk Tahun 2010. Jakarta: Badan Pusat Statistik.

Dinas Kesehatan Kabupaten Pati (2016) Profil Kesehatan Kabupaten Pati Tahun 2015. Pati: DKK Pati.

Dini, Li. I., Riono, P. and Sulistiyowati, Ni. (2016) 'Pengaruh Status Kehamilan Tidak Diinginkan terhadap Perilaku Ibu Selama Kehamilan dan Setelah Kelahiran Di Indonesia (Analisis Data SDKI 2012)', Kesehatan Reproduksi, 7(2), pp. 119-133.

Fadlyana, E., Larasaty, S. (2009) 'Pernikahan usia dini dan permasalahannya', Sari Pediatri, 11(2), pp. 136-140.

Ghony, D. (1997) Dasar - Dasar Penelitian Kualitatif. Surabaya: PT. Bina Ilmu. Hurlock, E. B. (1997) Psikologi Perkembangan: Suatu Pendekatan Sepanjang Rentang Kehidupan, Erlangga.

Ilika, A. and Igwegbe, A. (2004) 'Unintended pregnancy among unmarried adolescents and young women in Anambra State, south east Nigeria.', African journal of reproductive health, 8(3), pp. 92102. doi: $10.2307 / 3583396$. 
Jackson, S. and Goossens, L. (2006) 'Handbook of adolescent development', (2006) Handbook of adolescent development xiv, $419 \mathrm{pp}$ New York, NY, US: Psychology Press; US. Available at: http://ovidsp.ovid.com/ovidweb.cgi? $\mathrm{T}=\mathrm{JS} \& \mathrm{CSC}=\mathrm{Y} \& \mathrm{NEWS}=\mathrm{N} \& \mathrm{PAGE}$ $=$ fulltext $\& \mathrm{D}=$ psyc $5 \& \mathrm{AN}=2006-$ $13178-$

000\%5Cnhttp://vq2st5lq8v.search.s erialssolutions.com?url_ver=Z39.88

2004\&rft_val_fmt=info:ofi/fmt:kev: mtx:journal\&rfr_id=info:sid/Ovid:p syc5\&rft.genre=article\&rft_id $=$ in .

Kartikawati, R. (2014) 'Dampak Perkawinan Anak di Indonesia', 3(1), pp. 1-16.

khisbiyah yayah (1994) 'Konsekuensi psikologis dan sosiawekonomi kehamilan tak dikehendajk3 pada', $5(2)$.

Mulia, S. M. (2007) Islam dan Inspirasi Kesetaraan Gender. Edited by D. Al Asy'ari and M. HUda. Yogyakarta: Kibar Press.

Musthofa, S. B. and Winarti, F. (2010) 'MAHASISWA DI PEKALONGAN TAHUN 20092010 The Influencing Factors of a Pre-Marital Sexual Behavior Among College Students in Pekalongan'. Neamsakul, W. (2008) Unintended Thai adolescent pregnancy: A grounded theory study, ProQuest Dissertations and Theses. Available at: http://search.proquest.com/docview/ 304656089 ?accountid $=14553 \% 5 \mathrm{Cn}$ http://openurl.library.uiuc.edu/sfxlcl 3?url_ver=Z39.882004\&rft_val_fmt=info:ofi/fmt:kev: $m t x:$ dissertation $\&$ genre $=$ dissertation s+\%2526+theses\&sid=ProQ:ProQu est+Dissertations+\%2526+Theses+ Full+Text\&ati.

Palu, B. (2008) Menyelamatkan Generasi Muda. www.bappenas.go.id.

Petronio, S. (2002) Boundaries of Privacy: Dialectics of Disclosure. doi: MAI BF697.5 S427 P48 2002.

PKBI (2011) Studi Kasus Kehamilan Tidak Diinginkan Pada Remaja. Semarang: Persatuan Keluarga Berencana Indonesia.

Sriyasak, A., Akerlind, I. and Akhavan, S. (2013) 'Childrearing among thai first-time teenage mothers.', The Journal of perinatal education, 22(4), pp. 201-11. doi: 10.1891/1058-1243.22.4.201. 